\title{
1. Introduction, themes and structure of the book
}

\subsection{INTRODUCTION}

Encouraged by the reception of our first book on Singapore (The Singapore Economy, Edward Elgar, 1996), both within and outside Singapore, we offer a new and different analysis of this small but interesting economy. In our first book we tried to provide a macroeconomic and international trade overview of the economy, showing how the different parts fitted together, how the macroeconomic, monetary and exchange rate aspects were related. We also provided some macroeconomic theory to help readers understand the nature of the relationships between these different parts. That book was mainly historical and statistical and had very little institutional and historical detail and only briefly considered the problems associated with some of the policies and institutions that have been credited for Singapore's rapid economic growth. Some reviewers lamented that we were not able to discuss in greater detail some important institutions such as the Central Provident Fund, which has been used for macroeconomic purposes, but has also played an important role in shaping the nature of Singapore society and is not without its problems.

In this volume we offer an historical overview of the growth of the economy and the institutions and policies that made this rapid growth possible. This leads us to an examination of the current state of the economy and its possible future in terms of its prospective growth, structural change and the reforms that are currently being implemented and have been seen by some analysts as a paradigm shift in the government's thinking. An important factor in determining the nature of that future is the values and views of the current political leadership and their responses to current forces acting on the economy, and their own histories as well as that of Singapore. The Singapore system was created by one political party with a small core of policymaking cadres. Some narrations of its history just credit one person, so it is important to keep in mind the background of those who established that ruling party and set out to build a nation. Furthermore, generational changes in the leadership could lead it to consider a range of policies that would not occur to earlier generations. In outlining possible 
future paths of the economy we will therefore quote several Singaporean politicians and their ideas.

One of the authors of this book once remarked that many books about Singapore just seemed to be a string of quotations linked by a few general comments by the authors. Many writers could not resist quoting Lee Kuan Yew's early passionate defence of democracy, the jury system and individual rights and then his later justification of widespread interference in nearly all aspects of individual life. We will not rehearse such historical quotations but will seek to understand the ideas of the early Singaporean politicians and the views of those now in government and how they see the problems facing them and how they are trying to react to them. It might therefore be helpful to the reader who might not be familiar with the positions and functions of the principal people we will be citing, to mention them here. Their statements, often outside Singapore, give a good indication of the way the government wants the economy to develop. The most important people related to the Singapore government and its economic strategy we cite are the following:

Lee Kuan Yew, English-educated lawyer, founding member of the stillruling People's Action Party (PAP), defender of those interned under British colonialism and Prime Minister from 1959 to November 1990 when he stood down to become Senior Minister in the Prime Minister's Office. He retains his seat in parliament and is a member of the cabinet. $\mathrm{He}$ is generally known as 'SM' in the press and has recently produced two invaluable volumes on his life and the 'Singapore story' (Lee, 1998; 2000). Probably best known for advancing and defending 'Asian Values' in the 1990s which, in 1978, he had said was the necessary antidote against the infection of 'the disruptive individualism of western liberalism' that he thought had already infected Singapore (Hill, 2000, p. 185).

Goh Chok Tong, economist and civil servant who has been prime minister since November 1990. Undergraduate education in Singapore in economics and postgraduate in the United States in development economics. It was thought he would bring a gentler approach to politics and attitudes to opposition politicians but some Singaporeans do not think that has been the case. Generally known as 'PM' in the press. As a young civil servant he contributed a book chapter that argued that '[p]lanned industrialization as a conscious strategy of economic development in Singapore began only in 1961 with the establishment of the Economic Development Board' (Goh, 1969, p. 127). His most frequently used phrase in speeches recently seems to be 'every Singaporean counts'. In May 2001 he received the 'Distinguished Comrade of Labour' award from the trade union movement. 
Dr Goh Keng Swee, English educated economist and founding member of the PAP who is often identified as the economic architect of modern Singapore as he has been Minister for Education, Defence and Finance and Deputy Chairman of the Monetary Authority of Singapore at various times. His views are published in three volumes (Goh, 1972; 1977; 1995) and in some academic papers. Now retired.

Dr Richard Hu Tsu Tau, Minister for Finance since 1985, former chairman of the Monetary Authority of Singapore (MAS) and Chairman of the Board of Commissioners of Currency Singapore since 1985 so his signature appears on Singapore's currency notes. Undergraduate education in chemistry in the United States then postgraduate studies in chemical engineering in England. Career with Shell in Singapore and Malaysia before entering politics. Stood down from politics in October 2001 at the age of 75.

Brigadier-General (NS) Lee Hsien Loong, career military officer, in politics since the mid 1980s, currently one of the two Deputy Prime Ministers and, since January 1998, Chairman of the MAS, spearheading the reform and restructuring of the financial sector. Undergraduate education in England in mathematics and computer science then a mid-career programme of education in the United States. Usually serves as acting prime minister when the prime minister is out of the country and is widely expected to be the next prime minister. Some of his speeches on financial reforms are collected in Lee (2000b).

Brigadier-General (NS) George Yong-boon Yeo, Minister for Trade and Industry. Seems to be the face of the young PAP and spokesman for Singapore values and the Singapore spirit against unwanted foreign influences and articulator of the future for Singaporeans. Undergraduate education in engineering in England then MBA in the United States. Although keen on attracting foreign talent (see below) he is against Singaporeans working for foreign publications in Singapore, for example. He was formerly Minister for Information and the Arts and has been described as 'the New Guard's most original thinker' (George, 2000, p. 184).

C.V. Devan Nair, early member of the PAP and detainee under the British, who brought the trade unions under the control of the PAP. Served as Singapore's third President before resigning in March 1985. His speeches when in Singapore are available as Nair (1982) and Nair (1976) is also relevant. Now lives in exile and is a regretful and harsh critic of the political system in Singapore.

Dr Albert Winsemius, a Dutch economist and unpaid economic adviser to the Singapore government for many years and who has been described as the 'founding father of Singapore'. Dr Winsemius does not seem to 
have written much about his economic philosophy, except Winsemius (1962), but is referred to often in Singapore and also in Lee (2000). Winsemius (1982) refers to Singapore.

Interesting interviews with some of the first generation of PAP leaders and other important contributors to Singapore's early growth and institutional formation can be found in Chew (1996). One feature is that the younger leaders are more likely to have studied in the United States and thus possibly be more open to influences from there.

\subsection{THEMES}

In this volume we try to supplement and expand our earlier work in a number of ways as we review the nature of Singapore's economic growth experience by examining some related themes about the economy. Our historical focus mainly goes back to August 1965 when the independent nation state, the Republic of Singapore, was established but we do refer to the nature of the island and its economy before then and cite data going back to 1960. Singapore became self-governing in 1959 and was part of Malaysia from September 1963 to August 1965. Our main focus is on the years since 1965 and on the future.

\section{Growth and Development}

One important theme, reflected in the title of this volume, is the nature of the relationship between economic growth and development and how this is seen in Singapore. Singapore is always held up as an example of a rapidly growing economy that has, in the recent words of its Senior Minister in his memoirs, moved 'from third world to first' (Lee, 2000) but there are many in the government who do not believe that it is a developed economy. This was noted in Peebles and Wilson (1996, p. 243) where a PAP member of parliament was quoted as saying it absurd to think of Singapore as a developed economy and there has been reluctance within the government to agree to re-classifying Singapore in the official publications of international organisations as more developed (Wilson, 2000a). Singapore was proposed to be reclassified as a developed country by the Organisation of Economic Cooperation and Development in 1996, for example. Haggard (1999, p. 345) finds 'rather odd ... Singapore's current preoccupation with whether or not it is a developed country'.

The prospect of Singapore's becoming a developed country came to public attention in the early 1990s when the Economic Planning Committee 
of the Ministry of Trade and Industry published The Strategic Plan: Towards a Developed Nation which chose to use the term 'developed nation' in its title (Ministry of Trade and Industry, 1991). This reminds us that when Singapore became a sovereign nation in August 1965 it was not just concerned with economic growth but undertook to create an independent nation that would survive outside Malaysia. The object of the plan was to 'attain the stature and characteristics of a first league developed country within the next 30 to 40 years' (ibid., p. 2). This was seen not just in narrow economic terms but the economic dimension of the objective was that Singapore would aim to "catch up with - on a moving target basis - the GNP per capita of the United States by 2030 or the Netherlands by 2020'. This objective went beyond the then existing target adopted in 1984 of achieving the 1984 Swiss level of GNP per capita by 1999. The qualitative dimensions were for Singapore to concentrate on the quality of life, Singapore's national identity and to make it a global city. This strategic plan was very long-term and was not seen as a detailed blueprint as there were bound to be many unexpected events in that period and Singapore's size meant it was not able to control events. Although the committee expressed the difficulties of formulating a long-term plan for such a country it did stress that in the past Singapore had implemented three distinct plans that had been 'highly effective in achieving their primary aims' (ibid., p. 15).

The first plan was developed by a visiting team from the United Nations in 1960 led by Dr Albert Winsemius. Its primary objective was job creation, setting up the main planning body, The Economic Development Board, and developing four specific industries that he identified. (See Chapter 2 below for a discussion.)

The second plan came from the Ministry of Trade in 1980 with some advice from Dr Winsemius. By this time the economy was experiencing labour shortages and low productivity as it had embarked on industrialization by attracting multinational companies (MNCs) into labour-intensive sectors. This plan aimed at expanding the number of engineering and technical students at the tertiary level and tried to move employment away from labour-intensive sectors to higher value-added, technology-based sectors by pushing up wages.

The third plan was concerned with the perceived erosion of Singapore's international competitiveness in the early 1980s which preceded the recession of 1985-86. It was prepared by the Economic Committee established by the Ministry of Trade and Industry in 1985, and set out the long-term objectives of building wage flexibility into the economy and the promotion of the services sector.

These plans were brought about by specific problems at specific times: unemployment; labour shortages and low productivity; rising costs and 
recession. The Strategic Economic Plan of 1991 was much more ambitious and wide-ranging. Since its formulation there have also been many sectoral or topical plans and in the 1990s many strategies which were to realize some of the visions of the Strategic Economic Plan were given such names as Industry 21, Manpower 21, Retail 21, SME21, Technopreneurship 21, Trade 21, Tourism 21, to indicate their relevance for the new century.

The eight strategic thrusts of the 1991 Strategic Economic Plan were

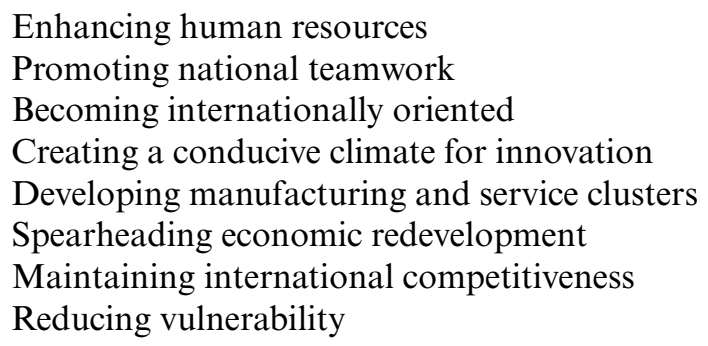

All of these themes reappear in subsequent plans and initiatives. The last one is worth looking at. Vulnerability at that time was seen as the economy's over dependence in certain areas. They were that the bulk of domestic exports came from the MNCs; that a large part of domestic exports went to the United States; that re-exports were still an important part of export earnings and that there was a high degree of reliance on crude oil imports from the Middle East. (The plan was being drawn up when the Gulf War broke out and the Soviet Union collapsed.) The committee thought that this situation had been created through the market mechanism so diversification could result in economic costs. They did identify two areas to increase diversification. MNCs should be encouraged to treat Singapore as a home-base for their activities and that local enterprises should be developed to world standards. These themes recur in subsequent strategies and plans. Vulnerability is still seen as over-reliance on some areas and since the plan was articulated concern has been expressed that in the manufacturing sector and amongst manufacturing exports there is too much specialization on electronic products. We will return to this aspect of the economy later.

Vulnerability does not necessarily come from over-dependence on certain products or markets and other aspects of Singapore's perceived vulnerability should be considered here. Government ministers keep stressing the vulnerability of the economy in language mainly aimed at stressing the importance that people keep voting for the People's Action Party (PAP) who have successfully managed the economy to its present state. People should pay no attention to opposition politicians who are held up as incom- 
petent and incapable of managing the economy and whose sole desire seems to be to get their hands on Singapore's reserves and squander them. Perceived vulnerability, partly due to the country's location and the way it became a sovereign national state in 1965, has always been stressed and has led to commentators attributing to the government 'a siege mentality'. People are kept frightened of the possible consequences of a change in government or even a fall in the percentage vote going to the PAP. The PAP picks the best to run the economy. As Lee Kuan Yew put it in the late 1980s: 'We decide what is right. Never mind what the people think', and shortly after that the then deputy prime minister, Goh Chock Tong, added, that Singapore's "intellectual elite" will continue to make the key decisions, while the proper role for the "rest of the nation" [is to] conform' (cited from Haas, 1999a, p. 6).

The other factor used to increase this sense of vulnerability and to limit self expression and public action is said to be due to the reliance on foreign investors, so university students have been told they cannot stage demonstrations as that would encourage workers to do the same, then foreign investors would lose confidence and the economy would collapse. National Service must be retained because if it were modified then foreign investors would lose confidence in the economy with the same results. The government seems keen to keep its people in fear of imminent collapse and the return to the low quality of life and standard of living of the colonial era. One aspect of this mentality is the government distrust of academics, especially in the social and political sciences, and of foreign press correspondents who are thought to be trying to influence the electorate and government (Lee 2000, p. 759) and of independent organizations in Singapore. The government wants to have a hand, and nearly always a controlling hand in everything. The Heritage Foundation, which still ranks Singapore as the second most economically free economy in the world, bluntly states that: 'The ruling People's Action Party (PAP) maintains firm control of all political and economic power' (The 2001 Index of Economic Freedom at http://database.townhall.com/heritage/index/country.cfm). Note their use of the word 'all'.

One result of Singapore's government-led growth strategy has been the creation of tensions between different groups in society. Locals and foreigners; the PAP itself and opposition parties; government-controlled companies and local, smaller enterprises; heartlanders (the prime Minister's term for the mainly Chinese educated working class who live in public housing estates) and the cosmopolitans (mainly English-speaking professionals who are internationally mobile), between Singapore and Malaysia. Tension between the first two groups has broken out at various times when foreigners have thought to be interfering too much in Singapore resulting in 
shows of Singapore's independence: the caning of Michael Fay is a good example. See Baratham (1994) and Latif (1994) for two interpretations of the significance of this event that affected American and Singaporean relations and Deck (1999, pp. 135-40) for the diplomatic row and its consequences. The expulsion of foreign journalists and the limiting of the circulation of magazines that are thought to have interfered in Singapore politics or have been unkind in their comments on Singapore's leaders or their wives is another example. The second tension is the basis of Singapore politics and can be seen in such seemingly trivial things as the fact that opposition-held constituencies - there are just two at present - are referred to as 'enemy territory' by the government-friendly press but more seriously in the limiting of public funds for opposition wards. There are problems connected with different perspectives of the progress of the different races also.

One aspect of the economy's vulnerability is that the possible defection of foreign firms and workers make Singapore a less attractive place to produce and work. This might not just be caused by events in Singapore but by changes in the perception of the region in general by foreign investors. One recently heard quip is that Singapore is a great piece of real estate but is just in a lousy neighbourhood. This became more of a worry for the government after the political changes and uncertainties in neighbouring countries that followed the Asian financial crisis. The political nature of Singapore seems to give it the confidence that it can prevent internal events from making the place less attractive to foreign investors but it has much less control over foreigners' perception of the region. In the late 1990s there was a clear shift in the government's tone as it tried to stress the uniqueness of Singapore and to distinguish it from neighbouring countries whereas earlier it had promoted Singapore to foreign investors as a springboard for venturing into the region with the help of government planning agencies. This new foreign policy thrust, which has also led to Singapore negotiating bilateral free-trade agreements with counties outside ASEAN (The Association of South East Asian Nations) founded in 1967.

The government's review of the implications of the finding of the 2000 Census provide another insight into its thinking on the nature of development and required policies. After favourably reviewing the changes in Singapore life over the years 1990 to 2000 BG (NS) George Yeo looked forward to what he expected the census of 2010 to show. He thought that 'we will probably have the economic, educational and cultural profile of a First World country' (The Straits Times, 21 February, 2001, p. H3), suggesting that there was still a long way to go to achieve this. He highlighted three major responses to possible problems on the way. First, the government would continue to encourage the importation of foreign talent for both quantitative and qualitative reasons. Second, the process of globalization 
meant that Singapore should diversify its links outside the immediate region and as Singapore would become a major capital exporter it had to look to such countries as India, China and Australia. The third response was to strengthen 'the Singapore spirit'. The threat of globalization was that more non-Singaporeans would come to live in Singapore just as more Singaporeans went overseas. It was necessary to strengthen the bonds with these overseas Singaporeans. One response was the decision in early 2001 to allow certain overseas Singaporeans to vote in future general elections. This possibility was put on hold in late 2001 as it was argued that the security situation after the terrorist attacks on the United States would make overseas voting too dangerous.

In terms of economic indicators it is easy to rank Singapore using consistent estimates of gross national product (GNP) per capita as published in the latest World Development Report 2000/20001. The latest data are for 1999 which will have allowed some time for the Asian economies to start recovery from the Asian Financial crisis. In 1999 Singapore's GNP per capita in purchasing power dollars was $\$ 27024$ which gave it a ranking of seventh in the world. This amount was 88 per cent of that of the United States, ranked fourth, 98 per cent of that of Switzerland, ranked sixth and 129 per cent of that of Hong Kong, ranked twenty-sixth in that year. Luxembourg, with a GNP per capital in purchasing terms of $\$ 38247$, is ranked first in the world by this criterion: being small is not a disadvantage. Singapore stands out as being far ahead of neighbouring countries where its GNP per capita was 3.4 times that in Malaysia, 11 times that in Indonesia and 4.8 times that in Thailand. The ratios for the Asian countries today are roughly the same as they were in the 1970s as all these countries have experienced similarly rapid growth since then. In contrast, the ratios to the more developed countries have risen considerably. In 1976 Singapore's GNP per capita was only 34 per cent of that in the United States and 30 per cent of that in Switzerland.

In terms of indicators of development other than narrow economic ones such as GNP per capita or other economic ones such as consumption per capita, Singapore does not rank as highly. We will examine the extent of these differences in Chapter 6. In general, most informal references to and appreciation of development use narrow economic indicators such as GNP per capita but individuals use other ways for themselves in assessing development. If, using the approach of the many millions of visitors to Singapore who assess its level of development by looking as its buildings, its transport system and shops, then Singapore already looks like a developed city that can be favourably compared to the cities of Western countries. If we take development to mean the ability to respond to external economic shocks and prevent major economic damage then, again, 
Singapore, would be ranked as developed. The Asian financial crisis which swept over the region after July 1997 did not lead to a major recession in Singapore. Growth stopped for a year and unemployment rose but did not reach crisis proportion and by the year 2000 the growth rate of real GDP returned to 9.9 per cent and foreign investments kept coming into the economy. Even a huge economy such as Japan perhaps does not deserve to be characterized as developed in this sense as it has been unable to respond successfully to an almost decade-long period of slow growth and declining prestige (Peebles, 1999b).

In January 2001 Singapore started a two-year term as a member of the 15-member United Nations Security Council and was its president for the month of January. This can be taken as recognition of developed status but we should note that such small countries as Jamaica, Tunisia and Ireland are also current members of the Security Council.

\section{Institutional Foundations of Growth and their Possible Future}

A second theme we examine is the nature of the institutions that have been able to secure rapid growth for Singapore and their relevance for the future. Are the institutions and policies that have been used successfully to secure economic growth in the past appropriate for the future development of Singapore as an economy and society? What reforms are being implemented, why, and what impact are they likely to have on the economy? How will the government's role change if it proceeds with plans for further liberalization and divestment of government-owned companies and statutory boards? The government is aware that the world has changed, partly because of the adoption of internet technology and the importance of research and innovation so that for Singapore to be successful in the future it must be 'part of the knowledge-based world.' (Lee, 2000, p. 763).

One aspect of prime ministerial behaviour that the present prime minister has inherited from his predecessor is the tendency to reveal more about Singapore policies and government thinking to journalists outside Singapore than at home. He has also adopted the Senior Minister's tendency to use 'you' to mean 'one' or 'me' or 'we'. This assumption makes the following revealing comments in a face-to-face interview with the Financial Times in 2000 intelligible. 'We have no choice. This is becoming a smaller and smaller world, and if Singapore is to survive into the future in this new economy, new world, it's got to embrace the cultures of the world. We are embracing globalisation and the IT revolution, convinced that they present more opportunities than costs.' And 'Can we be more entrepreneurial, more innovative, more creative within that model which we decide to have for Singapore? I think that's a basic question. Can you do it? I won't have 
the answer. Ten years from now, you can come back and ask me if we succeeded' (Goh Chock Tong quoted from McNulty, 2000).

When we look at the future of the economy we are not making our own predictions but will examine the trends in demography, technology and globalization that have been identified and look at how they may change the nature of the economy. In addition, we look at the government's own visions for the future of the economy. The extent of government intervention, planning and economic activity has been an important factor in the economy's past growth and it would be fair to say that Singapore is a planned economy that has used supply-side socialism for its development. Although all current government plans might not be realized they will, nevertheless, give us an idea of likely future developments in the economy.

\section{Nature of the Economy and Different Perceptions of Singapore}

Another theme we wish to pursue is to establish the nature of the economy and how that perception differs from that of other people and how their own perceptions differ so much. Between us we have lived in Asia for 33 years altogether and have worked in Singapore for 23 years. Our impressions of the economy are based on personal observation as well as hearing the views of the government, reading the analyses of people both within and outside Singapore, and becoming familiar with the economy and its data for our publications and our university teaching. Such institutions as the Central Provident Fund, the Inland Revenue Authority, governmentlinked companies such as the Development Bank of Singapore, the cooperatives operated by the trade union movement, the nature of immigration, taxation and academic bureaucracies, the standards of private and public medical care have all been part of our recent lives and are not just represented by abbreviations or acronyms on the printed page of some newspaper or book. Another consequence of our living in Singapore is that we will stress events that the outsider might think trivial and not at all commensurate with the great forces of demography, saving, investment, technology, trade and globalization that have transformed Singapore. Such seemingly trivial events and their interpretation by Singaporeans are important. Another consequence is that we have been able to see the introduction of certain policies and their effects and the extent to which they have been abandoned. Often analysts will highlight the introduction of a policy and leave the reader believing that it had the intended effect or that it was never withdrawn or significantly modified. That is not always the case.

It is surprising sometimes what influential people say about Singapore and the extent of disagreement over basic aspects of the economy they 
reveal. Partly this is due to the lack of official information on the role of government organizations in the economy and the confusing and incomplete way in which some information is presented, especially the government budget, balance of payments statistics and others. One government reaction to the Asian Financial Crisis was to call for more transparency in Singapore business and it is true that some government bodies have been more willing to talk about their policies and objectives, but this desired openness does not seem to have had an affect on the presentation of some statistical information.

In their very useful exercise in ranking the degree of economic freedom of different economies, Gwartney and Lawson (1997, p. 165) remark of Singapore that: 'Most of the enterprises are private (state-operated enterprises produce only a small portion of the total output) and there are few restraints limiting the entry into business.' This would be a great surprise to anyone who knows Singapore and what other people believe. Compare this view with that of Cardarelli et al. (2000, p. 9) who argue that: 'One likely cause of the weakness in microeconomic environment in the very high degree of government involvement in Singapore economy.' Not only do they believe there is a great degree of government involvement (note that they say 'involvement', not 'intervention') but that that factor has had harmful effects on the economy. They identify this involvement through the fact that public sector enterprises have been very active in production when they say that 'the business landscape in Singapore is characterised by heavy government presence, through the Statutory Boards and a large number of Government Linked Corporations (GLCs)'. The word 'presence' means that the government is in the business of production and is not only intervening through subsidies to foreign firms. It also obtains and allocates land and financial resources, forms companies and joint ventures with foreign investors and so on. Cardarelli et al. (2000, pp. 10-11) go on to show that government ownership of companies is higher in Singapore than in other Asian countries and that 'their overwhelming power is likely to have crowded out local private enterprise and thus prevented the development of a large and dynamic network of local corporations, contributing to the widely perceived lack of corporate dynamism in Singapore' (ibid., p. 11). One of our themes will be to examine how the government has tried, and is likely to try, to increase the degree of corporate dynamism in Singapore. This perceived lack of local dynamism is not only due to the presence of many public enterprises and bodies which have been accused of being rather conservative and risk-adverse in their activities but also to the fact that much of Singapore's technological base has been imported with the MNCs that have transformed the Singapore economy, and not through indigenous innovation and enterprise. 
In another comprehensive ranking of economies by their degree of economic freedom, in which Singapore is again ranked second after Hong Kong, Johnson et al. (1999, p. 346) evade the issue of the importance of GLCs. They argue that as 'neither the level of government ownership nor its level of expenditures for the GLCs is known exactly [as if it ever could be]; therefore, until the extent of the government's involvement in the GLCs is known with greater accuracy, Singapore is graded solely on the level of government consumption as a percentage of GDP, which remains very low by global standards'. This misses the point in a number of ways. We do not need to have an exact measure of something to know that it is significant in some way. We can find out the extent of government ownership and do have some idea of the significance of the output of public enterprises. Furthermore the amount of government consumption in GDP is not an accurate measure of the extent of government activity and influence over the allocation of resources. We should look at the proportion of resources the government can obtain and allocate, such as land, a large part of private saving and the extent to which it decides how these resources will be used, not relying on the decisions of private individuals. Alten (1995) did not take such a defeatist approach and apart from trying to identify the significance of the public sector in production using measures of ownership and control over GLCs he also looked at its role as 'provider of public merit goods', 'entrepreneur', 'planner' and facilitator' amongst other functions. In addition he surveyed managing directors of MNCs in Singapore to learn their views on how important the government was in a number of areas and how much and how the government affected their business. He attributes an important role to the government and concludes that 'Singapore's economic development is, above all, a political process, decided upon and guided by a strong government determined to overcome the country's backward economic status and to enter the first league of industrialised nations in the beginning of the next century' (Alten, 1995, p. 230).

For many years the annual review of the Singapore economy by the American Department of Commerce has stated that GLCs produce as much as 60 per cent of GDP (Singapore Economic Trends Report, p. 5), an estimate taken from a report from the Ministry for Finance of 1993. The Singapore government has not commented on this estimate until very recently when, in answer to a question in parliament, the Minister for Trade and Industry stated that it was wrong and, referring to then unpublished estimates stated that GLCs contributed only 13 per cent of GDP and foreign-controlled companies 42 per cent (The Straits Times, 24 February, 2001, p. H6, and Department of Statistics (2001) where they were subsequently published). The government is out to refute the view that GLCs have stifled local entrepreneurship. It is surprising to see that the 60 per cent 
figure was still being used in the foreign press as late as late March 2001 (Richardson, 2001, p. 24) in a publication that has been heavily fined for its reporting on Singapore. See Davies (1999, pp. 101-3) and Seow (1998, pp. 173-7) for accounts of the most recent attacks on it.

GLCs are not the only part of the pubic sector and we must keep in mind the economic role of statutory boards and ministries. One point to keep in mind is not necessarily the overall contribution to GDP of GLCs but their importance in certain industries and sectors where they can have a dominant market position (Department of Statistics, 2001, p. 1). These new estimates show the extreme importance in production of the MNCs. Foreign-controlled companies are those of which 50 per cent or more of their voting shares are owned by foreigners and can be branches or subsidiaries of foreign companies. We will see in subsequent chapters their even greater importance in different sectors.

The official view can be summarized in Table 1.1. A GLC is defined as a company if 'it is a subsidiary or associate, by virtue of share ownership, of Temasek Holdings (the government holding company) or a statutory board' (Department of Statistics, 2001, p. 3). Government ownership is considered to be the situation when the holding company holds more than 20 per cent of the voting shares. This seems to ignore the fact that there are three other government holding companies and that some companies are directly owned by government ministries. The public sector is the central government and statutory boards. The main facts that emerged from these estimates are that only 33 per cent of GDP in 1998 was produced by localcontrolled, non-state firms and that as much as 42 per cent of GDP came from foreign firms. Whether one concludes that GLCs have not crowded out local enterprise or not, it must be admitted that not much is produced by the indigenous private sector. Rectifying that is one of the current challenges facing the government.

Table 1.1 Production of GDP by type of ownership, 1998

\begin{tabular}{lc}
\hline & Share of GDP $\%$ \\
\hline Public sector & 8.9 \\
Corporate sector & 87.5 \\
Foreign-controlled companies & 41.5 \\
Local-controlled companies & 46.0 \\
$\quad$ of which GLCs & 12.9 \\
$\quad$ of which Others & 33.1 \\
Owner-occupied dwellings & 3.6 \\
\hline
\end{tabular}

Source: Department of Statistics (2001, p. 8). Cited with permission. 
It would be pointless presenting time series data showing that the share of the public sector has fallen from 16 per cent of GDP in 1990 to the 9 per cent of 1998 as this has mainly been accomplished by converting some statutory boards into companies, some of which, such as the Port of Singapore Authority, the government still completely owns. This has increased the share of GLCs in output slightly.

The nature of corporate ownership and the sectors in which they are significant can be seen by looking at the nature of the largest firms in terms of their sales or turnover. The largest ten according to Singapore 1000: Year 2000/2001 published by DP Information are shown in Table 1.2.

\section{Table 1.2 Largest firms in Singapore in terms of annual sales or turnover}

\begin{tabular}{lc}
\hline Company & Sales or turnover \$ billion per year \\
\hline Caltex Trading Pte Ltd. & 32.10 \\
Shell Eastern Trading (Pte) Ltd. & 12.56 \\
Hewlett-Packard Singapore (Private) Limited & 11.60 \\
Singapore Airlines Limited & 8.90 \\
SK Energy Asia P(Pte) Ltd. & 7.60 \\
Flextronics International Limited & 7.56 \\
Neptune Orient Lines Limited & 7.25 \\
BP Singapore Limited & 7.56 \\
Toshiba Capital (Asia) Ltd. & 6.43 \\
Mitsui Oil (Asia) Pte Ltd. & 6.02 \\
\hline
\end{tabular}

The significance of foreign-owned petroleum trading firms is clear. SK Energy Asia is a Korean firm that was only established in Singapore in 1990. The largest firm in the manufacturing sector is an American-owned electronics firm which is the second largest employer in Singapore, HewlettPackard Singapore. Flextronics International is an American electronics contract manufacturer with its headquarters in Singapore and operations in the United States. Singapore Airlines is a GLC as is Neptune Orient Lines, a shipping and logistics firm where the current prime minister made his reputation as an administrator. An important GLC such as SingTel ranks only eighteenth with a turnover of $\$ 4.87$ billion but would rank first amongst Singapore listed companies by market capitalization. Singaporeowned private firms, especially in manufacturing, do not feature near the top of the list. Two privately owned local banks are listed at twenty-ninth and thirty-sixth place. This review shows the significance of foreign firms in petroleum trading, electronics and chemical production.

The main reason for the differing views on the significance of the public sector is that the Singapore experience is often used to illustrate and 
support a particular view of economic development. In the case above, Gwartney and Lawson (1997) rank Singapore as the second most economically free economy in the world, after Hong Kong, and so it would be inappropriate to show the extent of the government's business operations, its control of the economy and the restriction of entry into production that that control has meant in the past. Public enterprises are usually thought of as socialistic and therefore inefficient so could not be part of a strategy that produced such high rates of economic growth as Singapore has achieved. Its public enterprises have not required massive subsidies from the state budget and statutory boards, with one exception, generated surpluses. Some had monopoly positions which, according to some analysts, were used to extract a surplus from the local population through their pricing policies for the purpose of development (Ermisch and Huff, 1999). Or, as Asher $(1999$, p. 1) puts it: 'The Statutory boards and the GLCs have used their monopoly power and absence of competition policies to set prices significantly above marginal cost to generate surpluses. As a result, their prices contain elements of taxation.' Evidence suggests that there is a 'relative lack of domestic competition in Singapore' (Cardarelli et al., 2000, p. 12) which is hard to reconcile with a high degree of economic freedom.

Surprisingly, The Heritage Foundation, which still ranks Singapore as the second most free economy in the world, states that GLCs 'dominate Singapore's economy, constituting up to 70 per cent of Singapore-owned companies and generating up to 60 per cent of GDP' and that there 'is increasing evidence of government intervention in Singapore's economy' which led to it being downgraded on this criterion (The 2001 Index of Economic Freedom). Their reaction to the new estimates will be of interest.

To some observers Singapore is an economically free paradise of a corporately organized economy which provides an efficient pro-business environment, especially for chosen foreign investors. To others it is an Orwellian nightmare of repressive social control of the local population in the interest of foreign capital (Tremewan, 1994; Terzani, 1998, pp. 161-3 and Chee, 2001) and where the 'official policy of the government is to keep the wage share in national income as low as possible, and correspondingly keep the share of capital as high as possible' (Asher, 1999, p. 1). This contrast and the nature of the political system has encouraged such writers as Haas to assume 'the task of presenting the Singapore puzzle out of respect for the successes of the country and chagrin over the excesses' (Haas, 1999b, p. 11). The nature of these 'excesses' were identified by the Dutch Labour Party in its criticism of PAP rule and in its attempt to expel the PAP from the Socialist International in 1976. It is ironic that a report was published by the trade union movement in Singapore in 1976 (Nair, 1976, pp. 250-67) in a volume of rebuttals and Singaporean documents entitled Socialism that 
Works: The Singapore Way, edited by C.V. Devan Nair and including the text of the Dutch Labour Party's complaints. The Singapore defence for its excesses in closing down newspapers, controlling the press, holding people in detention without trial, suppressing the trade union movement, student associations and suppressing intellectual freedom was that in the 1960s and early 1970s it was virtually in a state of war with communists. The point is that many of these policies remain today and Singaporeans see no justification for them, neither does the editor of that volume, C.V. Devan Nair, who served as Singapore's third President, referred to as 'Comrade President' by his brothers in the movement. He is now living in exile in Canada and is a harsh critic of how the Singapore political system has developed and sees it as the main impediment to development (Nair, 1994, and the interview with him in Chew, 1996, pp. 99-110).

Another conclusion drawn from Singapore's experience is the argument that democracy and a free press are not necessary for economic development and that 'soft authoritarianism' and discipline is better. This view is most closely associated with Lee Kuan Yew, Prime Minister from 1959 to 1990, and now Senior Minister. What Singaporeans are asking now is whether the degree of restriction and control that was used in the past was really necessary for the achievement of high growth and, more importantly, will that approach hinder future development of the economy? Here, again, the distinction between high growth rates and economic development and economic performance is important.

Another view sometimes drawn from Singapore's growth achievements is that socialism, the Singapore way, works. This was the claim of Dr Goh Keng Swee, widely regarded as the economic architect of modern Singapore, in an essay in a volume with that title (Nair, 1976, pp. 77-85). But that socialism has only worked as the government enthusiastically welcomed the creations of other countries' capitalist struggles: the efficient, globally-orientated foreign companies that have been attracted to Singapore by its supply-side socialist policies. Singapore has retained the bad aspects of socialism in the form of a one-party state, restrictions on some freedoms, the lack of independent interest groups described as civil society, government-controlled local media, no really independent trade unions and the seeming subservience of everything to economic growth and development as defined by the government. It has not replicated their dismal economic inefficiency. The argument formerly heard in Singapore is that democracy and a free press are not important for achieving growth, but will such a situation and the old approaches to politics and civil society serve the economy well in the future? Singaporeans such as Chee (2001, pp. 3-43) argue that Singapore could only be considered a developed county if it were a democracy and adopts the arguments of those such as A.K. Sen that democracy, 
or rather political freedoms of a higher level than found in Singapore, promote growth and that the evidence is that authoritarianism does not promote a good economic performance and that there is no real Asian tradition to rely on to justify Authoritarianism of the kind found in Singapore (Sen, 1997, pp. 1-2). With reference to Singapore we will have to ask whether its high growth rates really do indicate good economic performance.

Those economies that have emerged from the collapse of socialism have been attempting to develop opposition political parties, civilized political behaviour, civil society and truly independent broadcast and print media. They think they are important for both their future growth and development and entry into the international economic environment, a place where Singapore has always been. It is ironic that these factors were held up in Singapore, partly under the guise of Asian values, as the requisite for growth. Some of them such as huge savings rates, one-party rule, press and broadcast media that put the survival of the party first were key features of socialist economies and it is perhaps no surprise that Paul Krugman was led to compare Singapore with the former Soviet Union in his assessment of the nature of the Asian miracle. We will look at this argument and the controversy it provoked in Chapter 3. Will Singapore follow the trend of political liberalization or will it try to keep some of these old approaches in place?

The government has realized that such things as the internet have changed its ability to control the flow of much information and entertainment. The Singapore government, as did the Chinese, approached a Scottish company that had developed technology that allowed it to identify very quickly who was accessing what on the whole internet. The company declined to do business. In early 1999 it was revealed that SingNet (an internet provider and subsidiary of the GLC SingTel) together with the Ministry of Home Affairs scanned the files of all their 200000 subscribers. This was widely reported in the press which might indicate the transparency of the system but it also puts people on guard that their computers could again be scanned in a more subtle way. Internet access to overseas sites and internet communication is vital for the development of Singapore so it has talked less more recently about the potential of foreign viruses (ideas, not destructive programmes) that could affect Singapore. Internally, however, it tightened the rules relating to internet use by its own citizens in August 2001, especially in the political arena. Only registered political parties are allowed to use their web sites to announce their policies and discuss issues and so on. No other site can endorse candidates, display party material and slogans. This has been interpreted by some web sites that they can be prosecuted for political postings or statements put in their discussion groups and so two web sites decided to close down when the legislation was 
announced. One of the organizers of such a web site was also associated with a private organization recently established by former journalists and academics that aimed at monitoring the local press and providing an annual report on its standards. That organization closed down as it was unable to raise funds leading one former member to observe that there was a 'decreasing space for civil society in spite of all the talk about opening up with Singapore 21' (The Straits Times, 13 September, 2001, p. H4).

\section{The Asian Financial Crisis}

Throughout the book there will be reference to the Asian financial crisis. In some places it will be where we show how a particular sector was affected by this event or where we examine the policies adopted in reaction to it, how long-term strategies might be affected by it, or how the government has taken advantage of the crisis. The impact of the crisis has not finished and it has had a continuing and major effect on the political as well as economic sectors of Singapore's neighbours. Thailand became a client of the International Monetary Fund and is still suffering from its weaknesses in the financial sector and overinvestment in certain sectors. Malaysia spurned foreign help, became rather anti-Western, introduced capital control, pegged the currency and froze financial assets held by many Singaporeans. Politically, the deputy Prime Minister was removed and jailed, thus creating a new focus for new opposition political parties. Indonesia lost three Presidents and a colony and is suffering from an independence movement in various unstable provinces. Hong Kong retained its linked exchange rate system and so had to suffer domestic deflation caused by a severe recession as neighbouring currencies collapsed. South Korea became an IMF client and recovered quite quickly. Japan seems to be impotent in the face of a near-decade of stagnation. Throughout this there was no major crisis in Singapore. The banks and the financial system were not affected although they did experience an increase in non-performing loans, trade declined and so there was no growth in 1998. There was mild deflation, controlled depreciation of the currency and an increase in unemployment but there was no crisis. Expected government fiscal deficits did not emerge. In the early days of the crisis there were those who predicted it would turn into a worldwide recession that would be more severe than that of the 1930s. However, small, vulnerable Singapore did not bear the brunt of the crisis. This brought the risk of people becoming complacent about any future regional or international crisis as the government seemed able to ride the storm quite safely. Being small is not a disadvantage. Many of the reforms we are seeing now predated the crisis in conception but the crisis, and the reaction to it in other countries, might have forced the pace slightly. 
It would be wrong to attribute the current significant changes in strategy in Singapore to the impact of the crisis on Singapore itself, but more to technological and global changes and the way neighbouring countries have suffered from it, have declined in their attractiveness to foreign investors and how they have reacted themselves.

\section{Intellectual Foundations of Singapore}

This will be a minor theme that will be alluded to in places when we seek to link a certain set of policies to a possible intellectual ancestor or any other countries' experiences. Such a link might be purely accidental and perhaps not very clear. The PAP sees itself as a pragmatic party that does not draw on any ideology. Dr Goh Keng Swee has identified Adam Smith as his main influence and that Smith's ideas are enough for any developing economy, but for a more advanced one such as Singapore, David Ricardo could be consulted. We leave it to the reader to see if he or she can see any model or set of intellectual influences from which Singapore has drawn its approach to economic growth and the extent to which there are contradictions in any claims of intellectual influence. Goh Keng Swee has argued that Singapore is a socialist economy that works (Goh, 1977, pp. 94-106) and this might be hard to reconcile with the views of Adam Smith, though it has been said that one could construct a socialist tract from the Wealth of Nations. Goh's views, expressed in a speech to the Singapore Manufacturers' Association in 1969 were as follows:

What I want to do first tonight is to give an account of facts and figures to suggest that the PAP government are good socialists notwithstanding our genial relations with the capitalists. It is one of the fundamental tenets of socialism that the state should own a good part of the national wealth, particularly what is called the means of production. In this regard, that is state ownership of the means of production, it is my submission that the socialist sate of Singapore is not lagging behind the achievements of socialist governments in other parts of the world, probably ahead of most of them. In parenthesis, may I say when I use the term 'socialist' I exclude Communist states. (Goh, 1972, p. 183)

\subsection{STRUCTURE OF THE BOOK}

The book is organized in the following way. Chapter 2 reviews the nature of the institutions and policies that generated Singapore's growth and the role the political system has played. We intend to show the importance of the public sector in production and of the government in mobilizing and allocating resources; an importance that is not captured by just looking at the share of the public sector or GLCs in production. Further evidence of 
this latter feature will appear in subsequent more specialized chapters. We ask how the political system might change in the future and whether this will improve or hinder growth and development prospects.

Chapter 3 looks at the nature of economic growth. Much one-sided attention has been paid to the result of economic activity in the form of output growth rates but recently a debate has arisen about the efficiency with which those high growth rates had been achieved and whether such rapid growth is sustainable. We review some of this debate but argue that what is more important than the exact conclusions of the rapidly proliferating and contradictory academic studies is the nature of the government's response to that debate, the policies it adopted and what it thinks the growth prospects are. We thus review some official projections for future growth rates.

Chapter 4 looks at the structural changes in the economy in terms of expenditure components and the type of production. Expenditure patterns have changed in order to achieve extremely high rates of domestic saving and capital formation which has been accompanied by large current account surpluses leading to the rapid accumulation of foreign reserves which, on a per capita basis, are the highest in the world. We look at the possible justifications of such a policy later. In terms of the future structure of production we identify the extent and nature of the rise of the manufacturing and financial sectors and then look at some recent government statements of its strategy towards manufacturing.

Chapter 5 reviews the nature of the monetary, financial and fiscal aspects that accompanied and supported rapid growth and how the financial system is being restructured at present. The fiscal system and taxation policy reflects the PAP's desire to command financial resources and to avoid what it considers would be the debilitating effects of having a social welfare system. The nature of the actual social welfare system has had an important impact on the welfare of the population and so in Chapter 6 we examine aspects of welfare. That chapter also introduces other indicators of development apart from the narrowly economic, based on income per capita. One important point to note is that even these are misleading. What Singaporeans are interested in from their economic activity is not so much the level of income per capita and its growth rate but the level of their incomes. The presence of many foreign companies and foreign workers in the economy means that about one-third of GDP is earned by foreigners so that the income per capita of Singaporeans is less than the usual figure of GNP per capita that is used in international comparisons. Of course, other countries should adjust their GNP data to identify the earnings of their nationals and in some they would also have to reduce the GNP per person, but probably not by as much as the Singapore figures are reduced. In addition, if we think of development levels 
in terms of how much people can consume now and were to make international comparisons of consumption per capita then Singapore's GNP figures would be very misleading as its growth strategy has required the highest saving rates in the world such that personal consumption is only about 40 per cent of GDP and government consumption is only about 10 per cent. The extent to which Singaporeans have and will be able to benefit from these high saving rates will be examined in a subsequent chapter. We also look at the changes in the distribution of income in Singapore as its experience has not followed some expectations and here, again, there have been contradictory statements about this experience.

Chapters 7 and 8 look at trade policy and the role it has played in growth as well as international financial and exchange rate aspects. Here the important issues for the future of the economy are its ability to develop further an international financial centre and the future role of the Singapore dollar, that is, the possible further internationalization of the Singapore dollar and what the government feels about this and the possibility of regional monetary cooperation. In Chapter 9 we review the nature of the Asian financial crisis recession in Singapore and how the government responded to it and the nature of the unexpected and severe recession in the economy in the year 2001. We conjecture that this might be seen in the future as a pivotal year in Singapore's development. We review some of our earlier conjectures and look at the likely changes in the future economy if the government implements those policies that it sees necessary to create a 'New Singapore'.

In trying to make this a more general and lighter book than our first offering we have tried not to clutter the text with a source for every statement of fact or interpretation although they are given when we feel it is a point that might not be obvious or might need direct justification. We have provided a list of suggested reading for each chapter that gives the main sources and more can be found in the references.

Appendix A provides some summary time series data that appear in the figures and the text, and the main sources of data on the economy. The annual macroeconomic data we use are the latest revisions of February 2001, which means that in subsequent official publications different numbers will appear. Our annual data run to the year 2000 and we cite quarterly data that include the first two quarters of 2001. Appendix B outlines the electoral systems for parliament and the presidency and the results of elections. Appendix C provides recommendations for readings for each chapter. We include some items of fiction and political texts in these suggestions as we want the reader to obtain a feeling for what life is like in Singapore as expressed by novelists and non-government politicians as well as by the official press.

In our earlier volume we limited ourselves to referring to a very limited 
number of web sites. In this volume they have become much more important, not only for information and data about Singapore but for access to newspapers, journals and speeches. We have tried not to clutter up the text with too many references for the points we make but we stand by our statements. 